\title{
Overwintering strategies of dominant calanoid copepods in the German Bight, southern North Sea
}

\author{
A. Wesche $\cdot$ K. H. Wiltshire $\cdot$ H. J. Hirche
}

Received: 7 August 2006 / Accepted: 13 November 2006 / Published online: 16 December 2006

(C) Springer-Verlag 2006

\begin{abstract}
Abundance, stage composition and reproductive parameters (egg production, egg viability, proportion of spawning females) of the four copepod species Acartia clausi, Centropages hamatus, C. typicus and Temora longicornis were measured at the long term sampling station Helgoland Roads (German Bight, southern North Sea) from September 2003 to May 2004 to study their overwintering strategies. A. clausi was overwintering as females with arrested reproduction from November to January. T. longicornis, which is known to produce resting eggs in the North Sea, had a pelagic population with all developmental stages present during winter and reproductive rates closely related to food concentrations. Although their females produced eggs in response to ambient food conditions, both $C$. hamatus and C. typicus were rare in the pelagic. The $C$. hamatus population returned in May, probably from resting eggs, whereas $C$. typicus depended on advection. The Centropages species seemed to be less adapted to pelagic life in winter than $A$. clausi and $T$. longicornis. Sporadic occurrence of large numbers of nauplii and young copepodids of $A$. clausi and Centropages spp. pointed to different overwintering strategies or more successful survival in adjacent regions and advection of them into the waters around Helgoland
\end{abstract}

Communicated by O. Kinne, Oldendorf/Luhe.

A. Wesche $(\square) \cdot$ H. J. Hirche

Alfred Wegener Institute for Polar and Marine Research, Am Alten Hafen 26, 27568 Bremerhaven, Germany e-mail: Anne.Wesche@awi.de

K. H. Wiltshire

Biologische Anstalt Helgoland,

Alfred Wegener Institute for Polar and Marine Research,

P.O. Box 180, 27483 Helgoland, Germany island. While $A$. clausi was decoupled from environmental conditions in late autumn and winter, the other species were able to respond to variations in the food environment. Thus, egg production of $T$. longicornis increased during an unusual autumn diatom bloom.

\section{Introduction}

In temperate seas, water temperature and plankton biomass show a pronounced seasonality. In the southeastern North Sea surface water temperature ranges between $-1{ }^{\circ} \mathrm{C}$ in winter and about $20^{\circ} \mathrm{C}$ in summer (Otto et al. 1990). Phytoplankton biomass in winter is low and consists mainly of small flagellates, whereas values up to $1,000 \mu \mathrm{g} \mathrm{C} 1^{-1}$ are found in spring, mostly dominated by diatoms (Hickel et al. 1992).

Zooplankton growth and reproduction generally peak in spring, when temperature and phytoplankton biomass increase. Small calanoid copepods (Acartia spp., Temora longicornis, Centropages hamatus, C. typicus and Pseudocalanus elongatus) dominate the zooplankton population, with up to $85 \%$ of abundance in spring and summer (Krause et al. 1995). In winter their abundance is very low (Greve et al. 2004).

Little is known on the overwintering strategies of small calanoid copepods and the factors controlling it. Due to hydrographic and food conditions, winter represents a season where these copepods have to survive in an adverse environment. With respect to food, microzooplankton and detritus might be important for copepod diet in times of low phytoplankton biomass (Marshall and Orr 1958) and cannibalism could also play a role (Landry 1978; Daan et al. 1988; Ohmann and Hirche 2001; Sell et al. 2001). Another strategy to bridge 
adverse conditions is dormancy, defined as a state of suppressed development (Danks 1987). In copepods, dormancy may occur in various ontogenetic stages, from resting eggs to arrested development in copepodids and adults (Dahms 1995; Marcus 1996; Hirche 1998). In the southern North Sea, some species disappear completely from the water column for several months (Hickel 1975; Fransz et al. 1991). For example, C. hamatus, which is only present as resting eggs on the sea floor during winter months (Engel and Hirche 2004). In contrast, T. longicornis is found as both resting eggs and pelagic stages (Engel and Hirche 2004; Halsband and Hirche 2001).

Hay (1995) pointed out, that a combination of producing hibernating stages and low productivity will maximize success to bridge adverse conditions. Species specific strategies may result in different overwintering success under changing environmental conditions. Thus in the North Sea, temperature has been increasing by $1.1^{\circ} \mathrm{C}$ since 1962 (Wiltshire and Manly 2004). The hydrography of the North Sea has changed (Beare et al. 2002), potentially due to a climate-related increased inflow of Atlantic water into the northern North Sea (Reid et al. 2003). An increase in North Sea colour index has been reported by Edwards et al. (2002). Wiltshire and Manly (2004) related a shift in phytoplankton succession to the warming of the autumn (October-December) temperatures. The mean diatom day of the algal spring bloom is delayed and shifted to the end of the first quarter of the year (Wiltshire and Manly 2004). The overall zooplankton community has shown a considerable shift since the 1990s, mainly due to the presence of sub-tropical species. Copepod abundance, which dominated the zooplankton community from the 1950 s to the late 1970 s, was declining; instead, meroplankton became dominant (Edwards et al. 2005). According to Edwards and Richardson (2004) temperate marine environments may be particularly vulnerable to phenological changes caused by climatic warming because the recruitment success of higher trophic levels is highly dependent on synchronization with pulsed planktonic production. In terms of marine phenological changes and climate, the plankton of the North Sea has been extensively studied using Continuous Plankton Recorder data (Edwards and Richardson 2004). It was found that the plankton community was responding to changes in sea surface temperature by adjusting their seasonality. More importantly the response to climate warming varied between different functional groups and trophic levels, leading to mismatch (Edwards and Richardson 2004).

So far causative explanations for different responses on the species level are rare. Abiotic stress should affect cooccurring species with different life cycle strategies differ- entially. For example species with overwintering strategies controlled by instrinsic processes like dormancy should react differently from those with just temperature and food dependent development. To understand phenology, detailed knowledge on its controls is a prerequisite. In this study we investigated the population dynamics of four dominant copepod species at the long term sampling station Helgoland Roads at Helgoland island (German Bight, southern North Sea) from autumn to spring to analyse their overwintering strategies. Thereby we built on earlier studies by Halsband and Hirche (2001) and Engel and Hirche (2004), but sampled with a higher temporal resolution during the winter months. In addition to reproductive parameters (egg production rate (EPR), proportion of spawning females, egg viability) and prosome length we determined stage composition with emphasis on the abundance of young developmental stages as indicators of successful growth.

\section{Materials and methods}

\section{Study area}

The long term sampling station Helgoland Roads is located between the main island Helgoland and the sand dune island $\left(54^{\circ} 11.3^{\prime} \mathrm{N}, 7^{\circ} 54.0^{\prime} \mathrm{E}\right)$ (Fig. 1). Water depth varies tidally between 5 and $10 \mathrm{~m}$. The island is situated in the centre of the German Bight, about $65 \mathrm{~km}$ off the German coast. The hydrography of the German Bight and specifically around Helgoland island is influenced by waters of different origins. Water of high salinity, which enters the North Sea from the Atlantic via the English Channel in the south and the Fair Isle Current in the north reaches the island from the central North Sea, west from Helgoland. The source of low salinity water comes from coastal currents north and northeast from Helgoland (Banner et al. 1980; Otto et al. 1990). In autumn and winter the influence of Atlantic water is more important than in spring and summer (Otto et al. 1990). Due to strong tidal currents and the shallow depth the water column around the island is permanently mixed (Radach et al. 1990). Very cold winters, with a monthly minimum temperature of $-1^{\circ} \mathrm{C}$ or less, occurred about every 10 years up to 1944 , but only once since 1960 (Wiltshire and Manly 2004).

\section{Sampling}

Surface water samples for temperature, salinity, phytoplankton composition and biomass were collected on all workdays at Helgoland Roads using a bucket. Surface water temperature was measured immediately. 


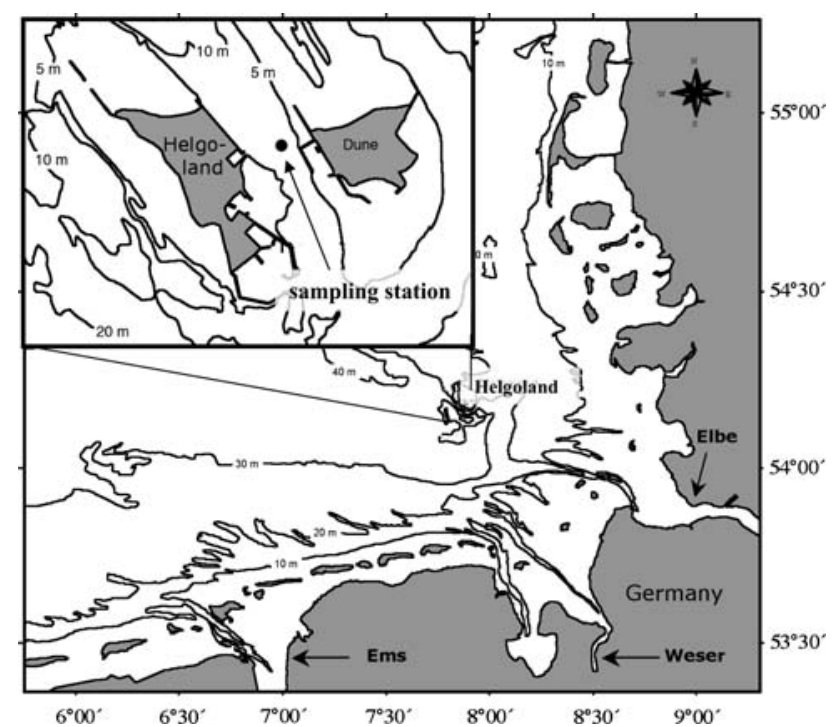

Fig. 1 Map of the German Bight, Helgoland island and the long term sampling station Helgoland Roads $\left(54^{\circ} 11.3^{\prime} \mathrm{N}, 7^{\circ} 54.0^{\prime} \mathrm{E}\right)$

The sample was gently mixed and sub-sampled into a glass bottle. A phytoplankton subsample was preserved with Lugols solution. Sub-samples $(25 \mathrm{ml})$ were counted to species level using the Utermöhl method and converted into carbon content with the program 'Count' (Tripos Inc., Germany), which works on the basis of calculations by Hillebrand et al. (1999).

Zooplankton was collected on 49 days from September 2003 to May 2004 in the morning, at least twice per month in vertical hauls from near the bottom to the surface. A Nansen net $\left(0.35 \mathrm{~m}^{2}\right.$ opening area, $150 \mu \mathrm{m}$ mesh size) was used for sampling adult copepods and copepodids and an Apstein net $\left(0.023 \mathrm{~m}^{2}\right.$ opening area, $55 \mu \mathrm{m}$ mesh size) for nauplii. Volumes of water filtered were measured using calibrated flow meters fitted in the net openings. Net samples were preserved immediately in $4 \%$ borax buffered formalin-seawater solution until analysis in the laboratory. Sub-samples of at least 150 copepods or nauplii were analysed for species composition except for two cases, where the entire sample contained less then 150 individuals. Calanoid copepods were identified to species level and stage (adults, copepodids CI/II, CIII, CIV/V, nauplii) except for Acartia spp., where only adult females were determined to species level. Nauplii of $C$. hamatus and C. typicus were not distinguished. The prosome length of at least 50 preserved females was measured once a month with a video-image digitising system (NIH Image 1.55) to the nearest $20 \mu \mathrm{m}$.

\section{Reproduction}

Egg production rate and proportion of spawning females of the four dominant calanoid species Acartia clausi, C. hamatus, C. typicus and T. longicornis were determined at least four times per month between September 2003 and May 2004. Live females were collected by oblique net tows (Nansen net, mesh size $280 \mu \mathrm{m}$ and Calcofi net, mesh size $500 \mu \mathrm{m}$ ) at Helgoland Roads. Samples were brought to the laboratory within $1 \mathrm{~h}$ and 30 active females per species were gently sorted with a pipette under a binocular microscope and placed individually in cell wells (Corning) filled with $10 \mathrm{ml}$ of $55 \mu \mathrm{m}$ prefiltered seawater. The wells were incubated at ambient temperature and light regime in an incubator chamber (WTB Binder). After $24 \mathrm{~h}$, females were removed and all eggs and eggshells were counted. Egg production rates (EPR) were calculated as the number of eggs spawned per female per day $\left(\right.$ eggs fem $\left.{ }^{-1} \mathrm{~d}^{-1}\right)$. To study hatching success, eggs were incubated in cell wells at in situ temperature and hatching was controlled daily for up to 10 days after spawning.

\section{Data analysis}

Stage specific abundance data of the four copepod species were $\log$ transformed $(\log +1)$ to show low abundances clearly. Temperature, salinity and phytoplankton components biomass were tested for autocorrelation. They were fitted to an ARMA model (Box and Jenkins 1976) to eliminate autocorrelation. Further analyses were done with the residuals of the fitted environmental data. Egg production rate, hatching success and proportion of spawning females had to be excluded from test of autocorrelation, because they did not fulfil the condition of time series analyses of regular time intervals between successive values. Sets of environmental and reproduction parameters were grouped by seasons and tested for significant seasonal differences by non-parametric Kruskal-Wallis test (Kruskal and Wallis 1952). Seasons were defined as follows: autumn, September-November; winter, December-February; spring, March-May. Egg production was correlated with the residuals of temperature and total phytoplankton biomass (PPC) by Pearsons Product Moment Correlation. All statistical analyses were performed with STATISTICA 6 (StatSoft Inc., Tulsa, OK, USA).

\section{Results}

\section{Hydrography}

Water temperature decreased from $18^{\circ} \mathrm{C}$ in September to a minimum of $3^{\circ} \mathrm{C}$ in March (Fig. 2a). Thereafter 

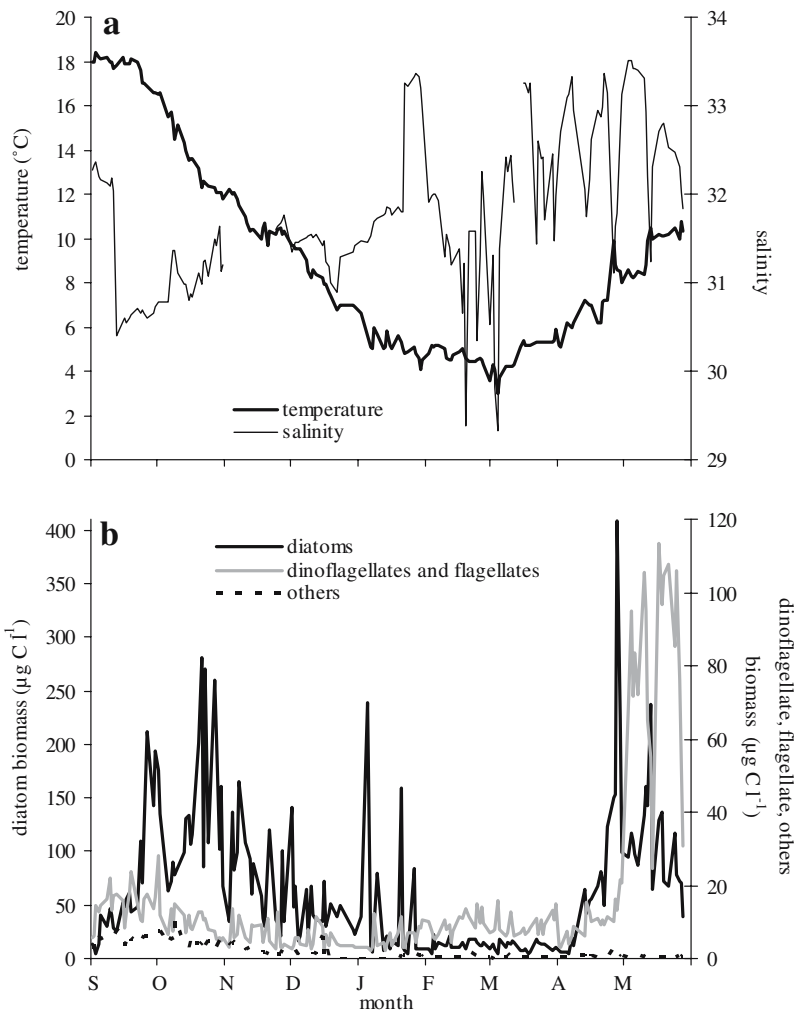

Fig. 2 Seasonal cycles of temperature and salinity (a) and phytoplankton biomass (b) at Helgoland Roads. others: ciliates, silicoflagellates, coccolithophorids and Noctiluca scintillans

temperature increased continuously to $10.4^{\circ} \mathrm{C}$ until the end of the study. Salinity showed strong variations with extremes of 29.3 (4th March) and 33.5 (3rd and 4th May). The lowest salinity was associated with the lowest temperature of $3^{\circ} \mathrm{C}$ on 4 th March. The KruskalWallis tests with residuals of temperature and salinity gave significant differences only in temperature between autumn and spring $(z=2.97)$ and winter and spring $(z=2.91)\left(H_{2,185}=11.51, P<0.01\right)$.

\section{Phytoplankton}

The phytoplankton consisted mainly of diatoms, flagellates and dinoflagellates (Fig. 2b). An autumn bloom of diatoms peaks with up to $250 \mu \mathrm{g} \mathrm{C} \mathrm{^{-1 }}$ in October and was followed by a minimum period with less than $25 \mu \mathrm{g} \mathrm{C}$ $1^{-1}$ from February to April, interrupted by strong short peaks in January (Fig. 2b). The maximum diatom carbon of $408 \mu \mathrm{g} \mathrm{Cl}^{-1}$ was observed at the end of April. Dinoflagellates and flagellates were present with low biomass until May, where they became abundant and amounted to nearly half of the phytoplankton biomass (Fig. 2b). Ciliates, silicoflagellates and coccolithophorids (combined as 'others') were present at mentionable numbers only from September to December. No significant differences between seasons within phytoplankton components were seen, after elimination of autocorrelation.

Copepod community structure and abundance

The copepod community in autumn was dominated by cyclopoid and harpacticoid copepods, which contributed more than $70 \%$ of the copepod population (Fig. 3a). While cyclopoid and harpcaticoid abundance decreased, from December on calanoid copepods became abundant and reached a proportion of more than $90 \%$ of the copepod population at the end of March. Total numbers of copepods decreased from about 7,000 ind $\mathrm{m}^{-3}$ in autumn to less than 1,000 ind $\mathrm{m}^{-3}$ in the winter months (Fig. 3b). Within the calanoid copepods we focused on four species (A. clausi, C. hamatus, C. typicus, T. longicornis). Paracalanus parvus, Pseudocalanus elongatus and Calanus spp. were combined as 'other calanoids' and were dominant from September until December (Fig. 4a). Individual numbers of the species investigated were below 1,000 ind $\mathrm{m}^{-3}$ from September until May, dominated by A. clausi and T. longicornis (Fig. 4b). The abundance of the two Centropages species was always low (max. 385 ind $\mathrm{m}^{-3}$ ).

Stage specific field abundances for the four copepod species were given as log transformed data (Fig. 5). For better understanding we gave the not transformed abundances in ind $\mathrm{m}^{-3}$ additionally in the text.

\section{Nauplii}

Nauplii of all species occurred during the entire study period, except in October and November, when Centropages spp. nauplii were absent (Fig. 5). Most of time nauplii outnumbered the other stages by far. They were usually dominated by Acartia spp. and T. longicornis. During autumn and winter months, their log abundance fell to less than 3.3 ind $\mathrm{m}^{-3}\left(<2,000\right.$ ind $\left.\mathrm{m}^{-3}\right)$. In spring, there was a strong increase in abundance in these two species, with peaks of $\log$ abundance of about 4.2 ind $\mathrm{m}^{-3}$ (maximum abundance 14,290 and 13,751 ind $\mathrm{m}^{-3}$, respectively). For Centropages spp. nauplii highest $\log$ abundance of 3.3 ind $\mathrm{m}^{-3}\left(1,855\right.$ ind $\left.\mathrm{m}^{-3}\right)$ was observed in October, while most of the time, their $\log$ number was less than 3 ind $\mathrm{m}^{-3}\left(<700\right.$ ind $\left.\mathrm{m}^{-3}\right)$.

Copepodids and adults

\section{Acartia clausi}

Three Acartia species have been reported from the North Sea: A. clausi, A. longiremis and A. bifilosa, with the first being predominant (Krause et al. 1995). As all 

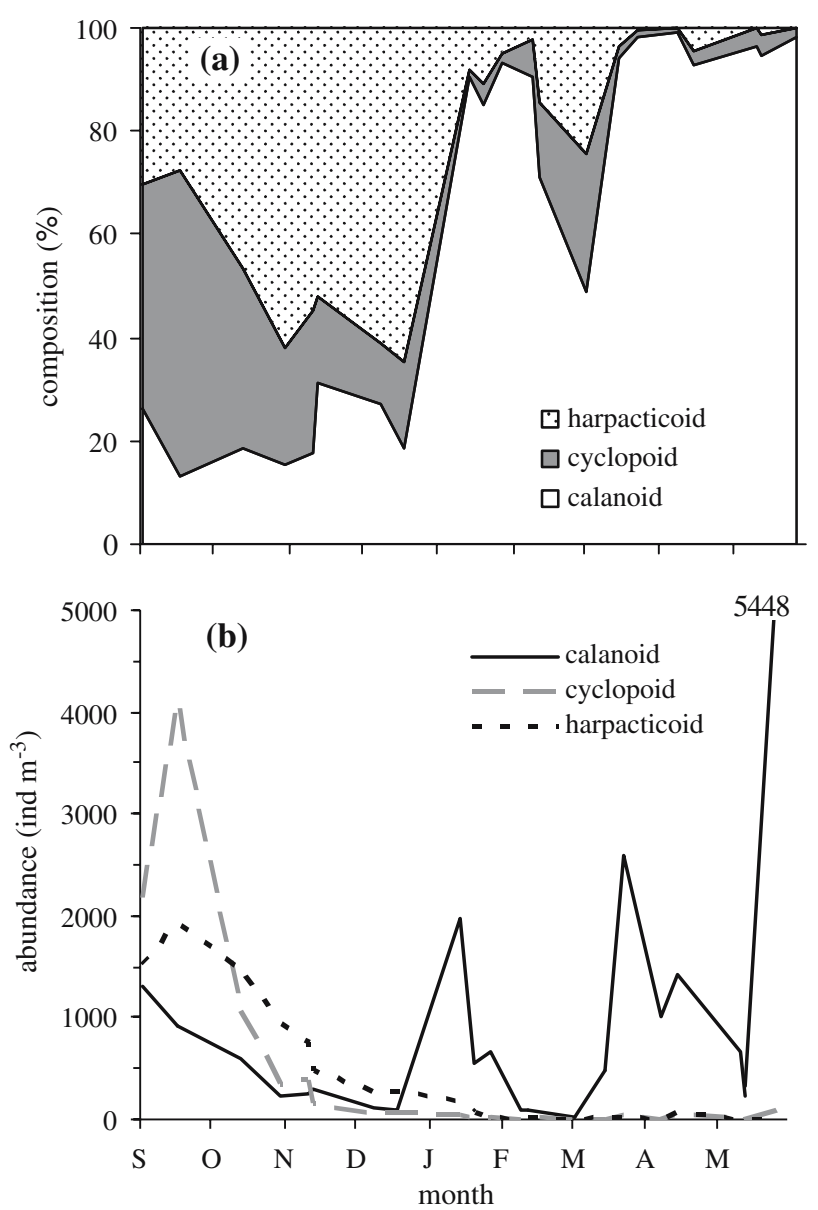

Fig. 3 Composition (a) and abundance (b) of the copepod community at Helgoland Roads

females determined in this study were $A$. clausi, we assumed the other stages belonging to this species, too. Copepodids and adults of $A$. clausi dominated the calanoid copepods (Fig. 4a, b). Their winter population consisted of older stages (CIV to adults) (Fig. 5). The log abundance of CIV and adults together decreased from 2.6 ind $\mathrm{m}^{-3}$ (400 ind $\mathrm{m}^{-3}$ ) in September to 1 ind $\mathrm{m}^{-3}$ $\left(10\right.$ ind $\left.\mathrm{m}^{-3}\right)$ in December, showed a short peak of about 2.8 ind $\mathrm{m}^{-3}\left(695\right.$ ind $\left.\mathrm{m}^{-3}\right)$ in January and increased from April up to 3.1 ind $\mathrm{m}^{-3}\left(1,172\right.$ ind $\left.\mathrm{m}^{-3}\right)$. From September to January, no adult males were observed. Afterwards the sex ratio was 1:1. Early copepodite stages (CI to III) became abundant in spring (log abundance 3.5 ind $\mathrm{m}^{-3}$, corresponds to 2,992 ind $\mathrm{m}^{-3}$ ).

\section{Temora longicornis}

Temora longicornis was second in abundance (Fig. 4a, b). Adults were present throughout the investigation, from September until March with log numbers of 1.6 ind $\mathrm{m}^{-3}\left(<40\right.$ ind $\left.\mathrm{m}^{-3}\right)$ (Fig. 5). Abundance of adults increased from April with a log maximum of 2.1 ind $^{-3}$
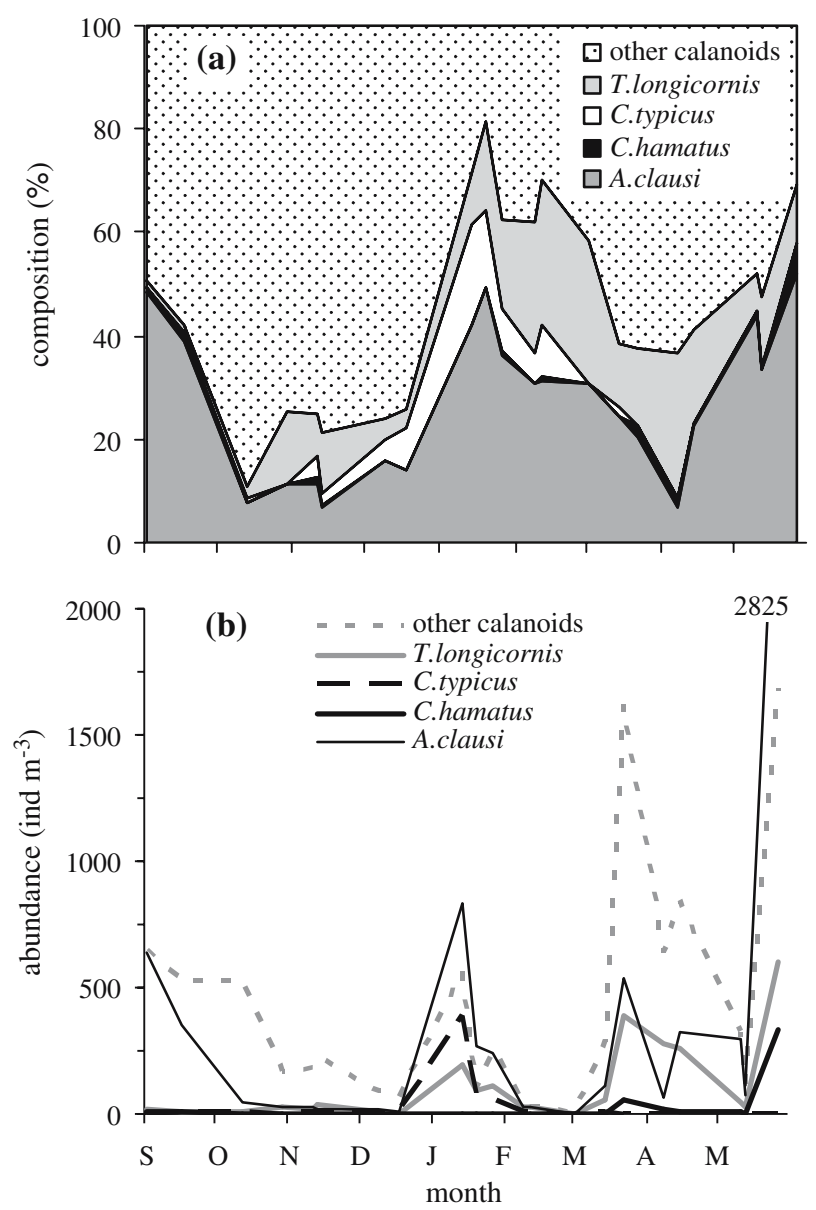

Fig. 4 Composition (a) and abundance (b) of calanoid copepods at Helgoland Roads. others: Paracalanus parvus, Pseudocalanus elongatus, Calanus spp.

(128 ind $\mathrm{m}^{-3}$ ) interrupted by a short decline at the beginning of May. The sex ratio was approximately 1:1. Copepodite stages CI to V showed low numbers until March, except a peak in January of 2.2 ind $\mathrm{m}^{-3}$ (162 ind $\mathrm{m}^{-3}$ ). In March, their log abundance increased and reached numbers of 2.7 ind $\mathrm{m}^{-3}\left(491 \mathrm{ind}^{-3}\right)$ in May.

\section{Centropages hamatus and Centropages typicus}

Copepodids and adults of Centropages spp. were less in numbers than the other species (Figs. 4, 5). Individuals of $C$. hamatus were almost absent from October until the middle of March, only a few adults occurred in September and January (log abundance 0.5 ind $\mathrm{m}^{-3}$, corresponds to 3 ind $\mathrm{m}^{-3}$ ). From March $\log$ abundance of all stages together increased to a maximum of 2.4 ind $\mathrm{m}^{-3}$ (246 ind $\mathrm{m}^{-3}$ ) in May. C. typicus also occurred only sporadically. An abundance peak of all stages was observed in the beginning of January ( $\log$ abundance 2.6 ind $\mathrm{m}^{-3}$, corresponds to 369 ind $\mathrm{m}^{-3}$ ), consisting mostly of older copepodite stages (CIII and CIV/V, log abundance 
Acartia clausi
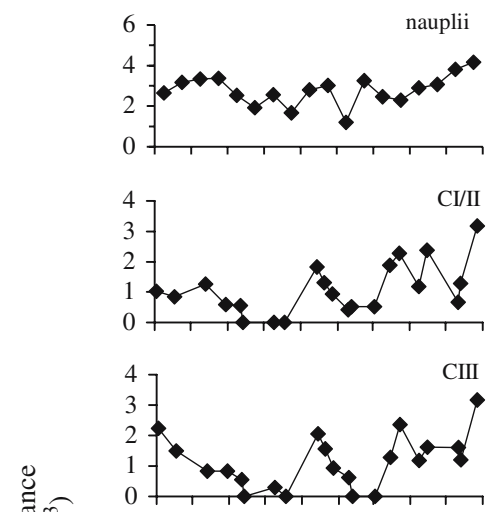

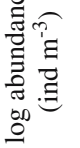
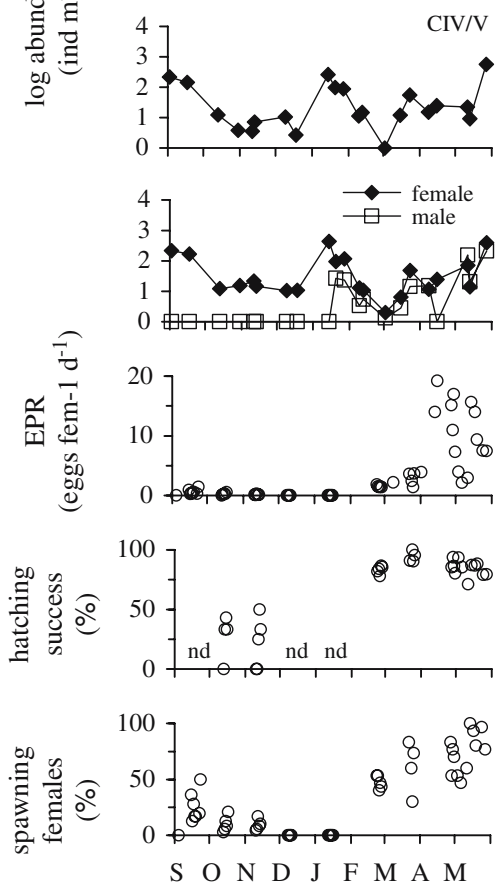

Centropages hamatus

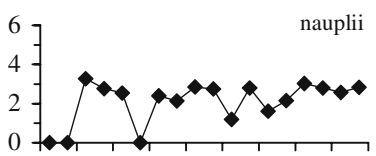

$\mathrm{C} / \mathrm{II}$
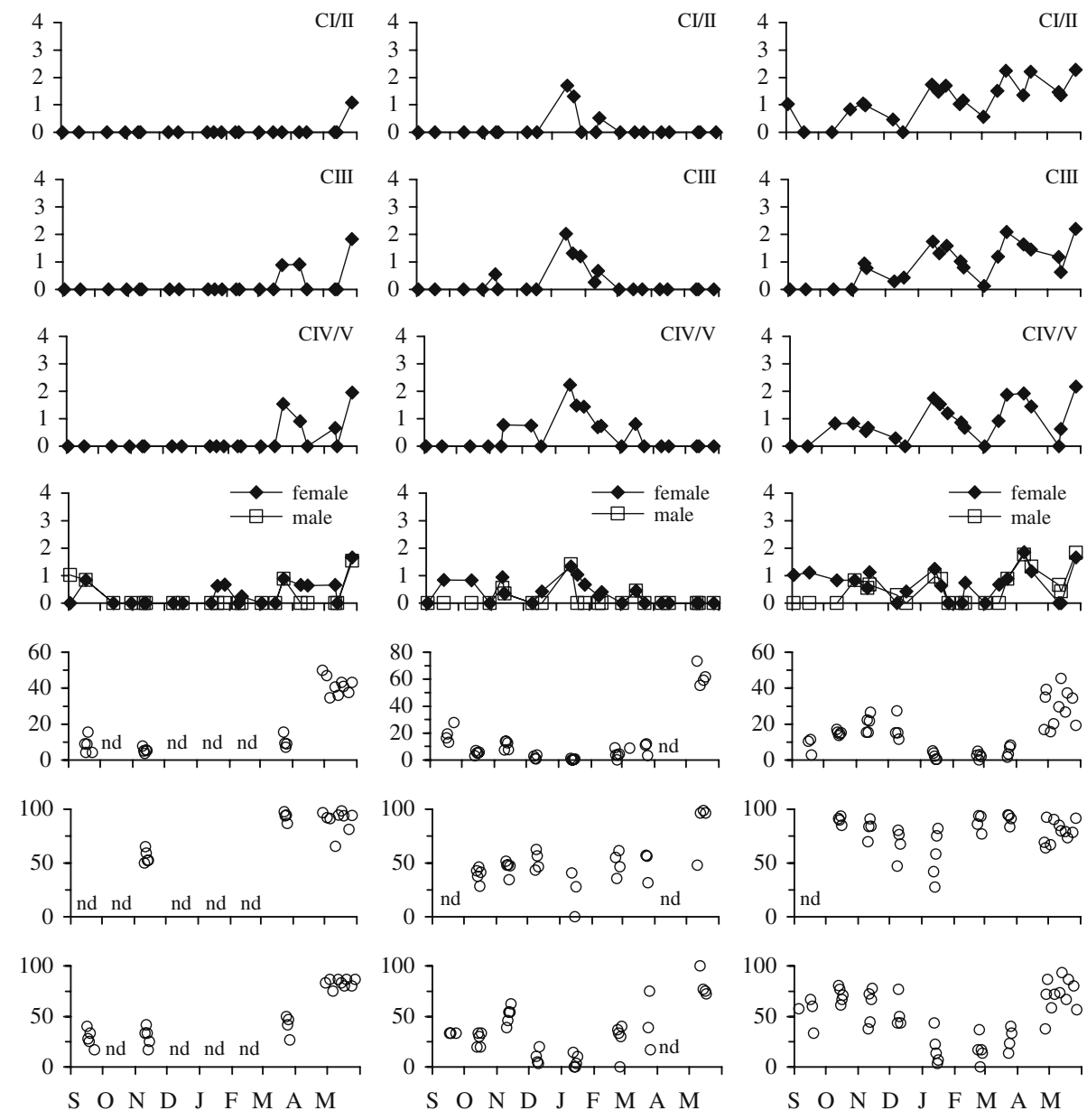

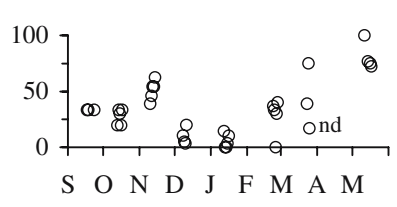

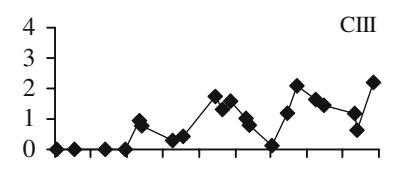
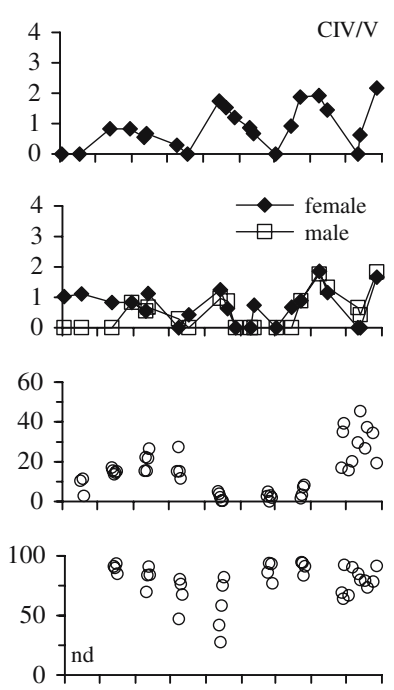

Temora longicornis
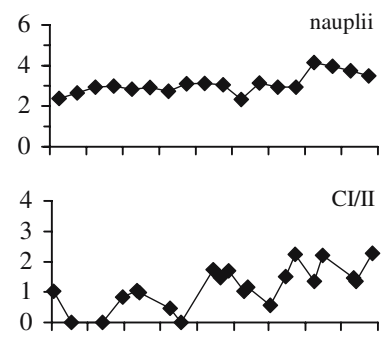

CIII

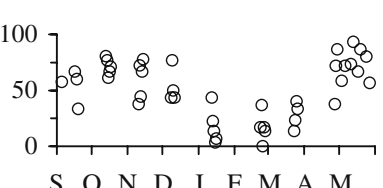

month

Fig. 5 Stage specific log abundances and reproduction parameters of four copepod species at Helgoland Roads. Note different scales. nd no data

2.4 ind $\mathrm{m}^{-3}$, corresponds to 274 ind $\mathrm{m}^{-3}$ ). The adult sex ratios of Centropages spp. were close to 1:1.

Reproduction and female size

Egg production and female sizes showed a general seasonal pattern of low values during autumn and winter and highest values in spring, but there were species specific characteristics (Figs. 5, 6).

\section{Acartia clausi}

Acartia clausi showed a pattern of discontinued reproduction with a clear disruption during winter and a springtime recovery (Fig. 5). There was no response of egg production to the autumn bloom. Egg production rate (EPR) was zero in December and January (Fig. 5). At the end of February, EPR began to increase suddenly, although there were no differences in the food environment to the previous months. Maximum EPR was reached in April with 19 eggs fem ${ }^{-1} \mathrm{~d}^{-1}$ and a proportion of spawning females of $80 \%$. Differences in EPR and proportion of spawning females were significant between autumn and spring, and spring and winter (Table 1). Hatching success in spring was also different to that in autumn (Table 1). There was no significant correlation between temperature or phytoplankton carbon and EPR (Table 2). Hatching success 


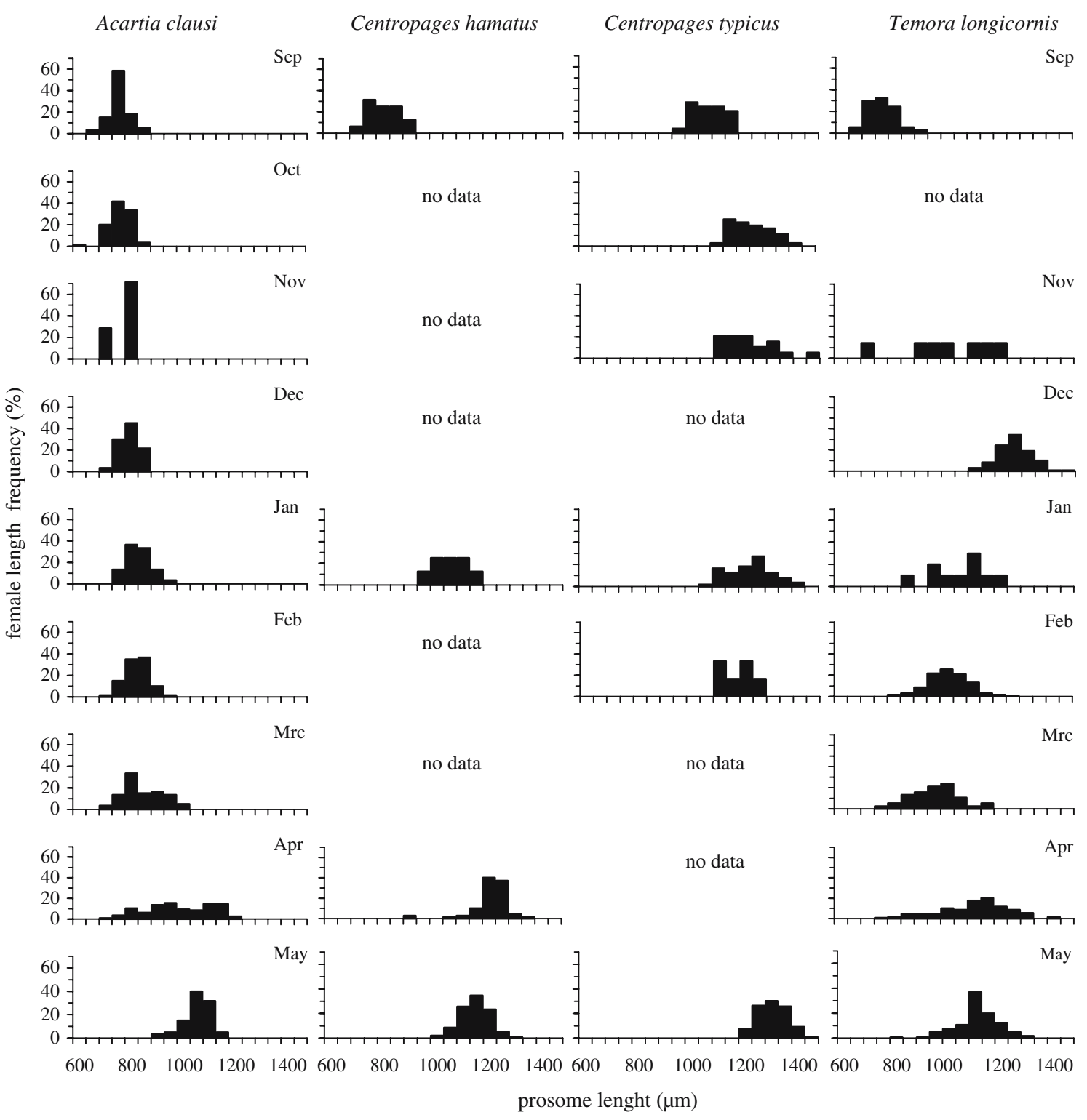

Fig. 6 Female length frequency distribution of four copepod species at Helgoland Roads

was low during winter $(<40 \%)$, but reached more than $80 \%$ in spring. It differed significantly between spring and autumn (Table 1). Female size remained nearly unaltered with a mean prosome length (PL) of $824 \mu \mathrm{m}$ from September to February (Fig. 6). From March on, larger females appeared. The largest females with $1,079 \mu \mathrm{m}$ were found in May.

\section{Temora longicornis}

Temora longicornis reproduced continuously throughout the study period, but EPR showed no coupling to temperature or phytoplankton carbon (Table 2). EPR up to 27 eggs fem ${ }^{-1} \mathrm{~d}^{-1}$ was reached in November and December, when the proportion of spawning females was about $60 \%$ (Fig. 5). From January to March, egg production declined to less than 10 eggs fem ${ }^{-1} \mathrm{~d}^{-1}$ and only $20 \%$ of females were spawning. Afterwards, EPR increased to 45 eggs fem $^{-1} \mathrm{~d}^{-1}$ and nearly $80 \%$ of females produced eggs. Egg production and proportion of spawning females were different between autumn and winter, and winter and spring (Table 1). Mean hatching success was always more than $60 \%$ with highest level of $90 \%$ in spring, but there were no significant differences between seasons (Table 1). T. longicornis had the tendency to larger females during spring, although the largest females with $1,199 \mu \mathrm{m}$ PL were observed in December (Fig. 6). Monthly mean female PL varied between 774 and $1,199 \mu \mathrm{m}$. 
Table 1 Acartia clausi, Centropages hamatus, Centropages typicus and Temora longicornis. Seasonal comparison between reproduction parameter by Kruskal-Wallis test

\begin{tabular}{|c|c|c|c|c|c|c|c|c|c|c|c|c|}
\hline \multirow[t]{2}{*}{ Season } & \multicolumn{3}{|c|}{ Acartia clausi } & \multicolumn{3}{|c|}{ Centropages hamatus } & \multicolumn{3}{|c|}{ Centropages typicus } & \multicolumn{3}{|c|}{ Temora longicornis } \\
\hline & $\begin{array}{l}\text { EPR } \\
(52)^{* * *}\end{array}$ & $\begin{array}{l}\text { Spawn } \\
(52)^{* * *}\end{array}$ & $\begin{array}{l}\text { Hatch } \\
(34)^{* * * *}\end{array}$ & $\begin{array}{l}\text { EPR } \\
(23)^{* * * *}\end{array}$ & $\begin{array}{l}\text { Spawn } \\
(23)^{* * * *}\end{array}$ & $\begin{array}{l}\text { Hatch } \\
(18)^{* * *}\end{array}$ & $\begin{array}{l}\text { EPR } \\
(36)^{* * *}\end{array}$ & $\begin{array}{l}\text { Spawn } \\
(36)^{* * *}\end{array}$ & $\begin{array}{l}\text { Hatch } \\
(31)^{*}\end{array}$ & $\begin{array}{l}\text { EPR } \\
(42)^{* * *}\end{array}$ & $\begin{array}{l}\text { Spawn } \\
(42)^{* *}\end{array}$ & $\begin{array}{l}\text { Hatch } \\
\text { (36)ns }\end{array}$ \\
\hline $\begin{array}{l}\text { Autumn versus } \\
\text { winter }\end{array}$ & ns & ns & ns & nd & nd & nd & 3.62 & 2.69 & ns & 2.47 & 3.26 & ns \\
\hline $\begin{array}{l}\text { Autumn versus } \\
\text { spring }\end{array}$ & 4.84 & 4.73 & 4.63 & 3.60 & 3.66 & 3.20 & ns & ns & 2.42 & ns & ns & ns \\
\hline $\begin{array}{l}\text { Winter versus } \\
\text { spring }\end{array}$ & 5.28 & 5.14 & ns & nd & nd & nd & 4.02 & 3.82 & ns & 3.70 & 3.11 & ns \\
\hline
\end{tabular}

Numbers in parantheses, Significance levels $* P<0.05 ; * * P<0.01, * * * P<0.001$

$n s$ not significant, $n d$ no data, EPR egg production rate, spawn proportion of spawning females, hatch hatching success

Table 2 Correlation coefficients $(r)$ between egg production rate (EPR) of four copepod species and residuals of temperature $(T)$ and total phytoplankton biomass (PPC) at Helgoland Roads

\begin{tabular}{lllll}
\hline & Acartia clausi & Centropages hamatus & Centropages typicus & Temora longicornis \\
\hline EPR/T & $0.021(52)$ & $0.159(23)$ & $0.353^{*}(36)$ & $-0.025(42)$ \\
EPR/PPC & $0.199(52)$ & $-0.251(23)$ & $0.189(36)$ & $-0.011(42)$ \\
\hline
\end{tabular}

Sample size in parentheses

Significance levels $* P<0.05$

\section{Centropages hamatus and Centropages typicus}

Egg production of C. hamatus was low in autumn and only $30 \%$ of the females produced eggs on the few dates where experiments were conducted (Fig. 5). In spring, reproduction increased and reached values up to 49 eggs $\mathrm{fem}^{-1} \mathrm{~d}^{-1}$ in May with a proportion of spawning females of $80 \%$ and hatching success more than $90 \%$ (Fig. 5). Egg production, proportion of spawning females and hatching success of $C$. hamatus differed significantly between autumn and spring (Table 1), but no correlation between EPR and temperature or phytoplankton was seen (Table 2). Female size varied between $824 \mu \mathrm{m}$ in September and 1,266 $\mu \mathrm{m}$ in April (Fig. 6).

Centropages typicus showed egg production of less than 20 eggs fem ${ }^{-1} \mathrm{~d}^{-1}$ from September to March. The maximum EPR of 73 eggs fem ${ }^{-1} \mathrm{~d}^{-1}$ occurred in May. EPR and proportion of spawning females were significantly different between autumn and winter, and winter and spring (Table 1). There was a significant correlation between EPR and temperature (Table 2). The percentage of spawning females varied between $5 \%$ in January and $81 \%$ in May. Hatching success varied from 27 to $62 \%$ from October to April and reached its maximum of $99 \%$ in May. Differences in hatching success were seen between autumn and spring (Table 1). Females of $C$. typicus were the largest ones with a maximum mean PL of $1,324 \mu \mathrm{m}$, occurring in
May (Fig. 6). Smallest females with 1,087 $\mu \mathrm{m}$ appeared in September.

\section{Discussion}

Harpacticoids and cyclopoids dominated the copepod community of the southern German Bight in autumn, but from December on calanoids became the most important group, confirming results of previous studies (Fransz et al. 1991; Krause et al. 1995; Halsband and Hirche 2001; Halsband-Lenk et al. 2004). This predominance indicates proper adaptations to winter conditions in the pelagic.

We distinguished different overwintering strategies in each of the species of calanoid copepods investigated around Helgoland island, using stage composition together with reproductive parameters and female prosome length.

Acartia clausi was the most abundant calanoid during the study. Its reproductive parameters mirrored very closely the observations by Halsband and Hirche (2001) during the winter 1995/96, although temperatures then were significantly lower. In both studies, females were the most frequent stage (nauplii were not studied by Halsband and Hirche 2001), followed by copepodite stages CIV/CV. Spawning activity was low in autumn and zero in December and January. Number of spawning females and egg viability increased 
conspicuously in February. Low hatching success in autumn could relate to the scarcity of males, as e.g. Acartia tonsa one mating is usually not sufficient (Wilson and Parrish 1971). Otherwise, the complete cessation of reproductive activity at the end of autumn during a time when food was available and initiation of egg production during a time of lowest food concentrations indicate instrinsic control, and an arrested reproductive dormancy (Hirche 1998). In this case low hatching success could be a result of preparation of the gonads for dormancy. A female diapause was described for the congener Acartia longiremis in a North Norwegian fjord (Norrbin 2001). The factors causing the arrested reproductive activity are not known. In other regions like the Mediterranean A. clausi reproduces year round, with winter and spring as the main spawning season (Gaudy 1972; Ianora and Buttino 1990). As temperatures are not too different then from autumn temperatures in the North Sea, temperature is not a likely cue. Closer examination is needed to identify the nature of this dormancy in A. clausi. Female prosome length further supports the concept of an overwintering strategy based on reproductively inactive females, as it remained rather constant from September to April. In contrast, in the Mediterranean females size changes continuously, also during the winter (Riccardi and Mariotto 2000).

The general strategy is, however, obscured by the irregular occurrence of relatively large numbers of younger copepodids and nauplii on several occasions, but especially in January. From this time on also slightly larger females were present. The lack of a clear stage succession together with the reproductive inactivity excludes local development, but rather points to advection, the more so, as in January strong changes in salinity were recorded. Thus, these individuals originate either from adjacent regions where $A$. clausi has another overwintering strategy, or they represent offspring of the congeners $A$. longiremis and $A$. bifilosa. As nauplii and young copepodids of Acartia spp. were not determined to species level no clear assumption could be made. Evidence of resting eggs of Acartia spp. as a source of nauplii is missing in the Atlantic and the North Sea (Naess 1996; Engel and Hirche 2004). However, the congener $A$. bifilosa is known to produce resting eggs (Castro-Langoria and Williams 1999), but is usually rare in the southern North Sea (Krause et al. 1995).

Reproductive parameters clearly indicate the end of February as the beginning of the new growth period around Helgoland island. The first new generation was completed then by April, as indicated by a different female size distribution. This period corresponds well with developmental times at the respective temperatures derived from laboratory rearings (Klein Breteler and Schogt 1994).

In contrast to A. clausi, stage composition of $T$. longicornis was characterised by the almost permanent presence of all stages throughout the investigation. Females produced eggs at much higher rates than A. clausi. Egg production followed closely the seasonal cycle of phytoplankton; low rates were only found in January and February. From September to March, hatching success and the number of spawning females was almost higher than in $A$. clausi. Female size increased already in November, indicative of a new generation developed at lower temperatures. As the reproductive parameters were very similar in 1995/96 (Halsband and Hirche 2001), we conclude that the overwintering strategy of $T$. longicornis in the German Bight be characterised in general by active growth and reproduction in response to its nutritional environment. Thus, it was the only species, which responded to the late autumn peak in diatom biomass with enhanced reproductive activity. However, T. longicornis is also known to produce resting eggs in the North Sea (Lindley 1986, 1990; Engel and Hirche 2004). The strong increase in nauplii abundance observed one month before the spring bloom and the maximum egg production may at least in part originate from resting eggs. According to Castellani and Lucas (2003) resting eggs of $T$. longicornis were mainly produced during spring and late summer, at the peak of the reproductive season. We found no clear evidence of a higher production of resting or diapause eggs during spring; the hatching success did not decrease. Thus, resting eggs have to be produced later in season. The mixed strategy of active growth and low reproduction in winter together with the production of resting eggs may minimise mortality from predation pressure, prevent intraspecific competition (Engel and Hirche 2004) and ensures the survival of the population during extremely severe winters.

In $C$. hamatus copepodids were almost completely absent from October 2003 until March 2004. Adults were extremely rare from September onwards and recurred in February. Whenever females were available in the samples they produced eggs. Egg production was moderate until November and in April, but increased rapidly in May, as reported before by Halsband and Hirche (2001). In the German Bight around Helgoland island (Engel and Hirche 2004) as in other locations of the North Sea (Lindley 1986, 1990) C. hamatus overwinters mainly through resting eggs. As nauplii of the congener $C$. typicus were not distinguished here we could not prove emergence from resting 
eggs. The overwintering of $C$. hamatus in the southern North Sea resembles the mixed strategy of $T$. longicornis, but the survival of the pelagic population seems to be less successful, was it due to inadequate food conditions, or to predation. In contrast, C. hamatus in the Kattegat (Kiørboe and Nielsen 1994), the English Channel (Le Ruyet-Person et al. 1975) and the Irish Sea (Castellani and Lucas 2003) is abundant in winter and reproduces throughout the year. So, the few individuals found during winter might be advected into the waters around Helgoland.

Centropages typicus has been considered as a sporadic immigrant in the North Sea or was not mentioned in earlier studies (e.g. Rae and Rees 1947; Wiborg 1955; Fransz 1975; Hickel 1975). However, in recent years it becomes more abundant, especially from late summer to winter (Hay 1995; Halsband-Lenk et al. 2004). Lindley and Reid (2002) suggested population centres of $C$. typicus in the German and the Southern Bights, persisting throughout the winter. Halsband and Hirche (2001) observed this species between September and January also around Helgoland island. During this study it was found only sporadically and was absent in 9 out of 21 quantitative vertical tows. Stage composition was not consistent and did not show a succession of stages, but included different combinations of stages. Large abundances of all stages were observed on two occasions in January, probably due to advection. Advection from adjacent regions would underline the existence of pelagic winter population in northern and western regions (Lindley and Reid 2002). The female size shift from September to October indicated the arrival of another generation, which then persisted throughout this study. Egg production continued during winter with the exception of January, when no eggs were laid. Hatching success was never higher than $50 \%$ until May. This is in contrast to the other species investigated, which showed shorter periods of low hatching success. In May, when egg production increased dramatically, also hatching success was high. So far, no indication of resting eggs was found for C. typicus (e.g. Ianora and Scotto di Carlo 1988; Miralto et al. 1995; Engel and Hirche 2004). Lindley (1990) supposed dormancy of such eggs in sediments, but in experiments much less nauplii hatched compared to its congener $C$. hamatus. Thus, there seems to be no specific adaptation to winter conditions and the population continues its development during winter depending on food conditions. Due to unfavourable conditions it is dying off before the end of winter.

In their review on the phytoplankton dynamics of the North Sea, Reid et al. (1990) pointed to the great complexity of phytoplankton dynamics in the North
Sea and the fact that algal successions and blooms often do not follow classical patterns. This applies also to the period of our investigation. The phytoplankton succession in 2003 was rather unusual. While mostly phytoplankton carbon drops to below $30 \mu \mathrm{g} \mathrm{C} 1^{-1}$ in late summer and remains very low until April of the following year, the autumn bloom in 2003 was associated to a relatively high phytoplankton biomass until the end of December. Our data showed that only one copepod species could benefit from this opportunity. As the pelagic population of $T$. longicornis perpetuates actively during the winter, it was able to respond to the autumn bloom with an increased reproductive activity. The fact that it also has resting eggs on the sea floor as an additional safeguard illustrates the risk of a pelagic strategy without adaptation. Female $C$. hamatus and C. typicus seemed also to possess the potential to reproduce when food is sufficient, but their mortality was obviously so high that the pelagic populations died off during winter. Finally, in A. clausi reproduction is decoupled from environmental changes during autumn and winter. However, their late winter arousal should make especially this species sensitive to the timing of the spring bloom.

The general picture of overwintering strategies we found was disturbed by sudden abundance peaks consisting often of very young stages. The most conspicuous peak was observed in January and affected the stage compositions of all species except $C$. hamatus. It was most likely associated with an advective event from the western or northern parts of the North Sea, typical in winter at Helgoland Roads (Banner et al. 1980; Otto et al. 1990), as seen in the continuous increase in salinity during our study. Advection of populations with different stage composition indicates, that the overwintering strategies observed here are effective only on a regional scale, and that other strategies are in effect of adjacent areas.

So far, overwintering of calanoid copepods in the southern German Bight is controlled and affected by a combination of several factors, whose impacts are species specific. Within this, food, temperature and advection seemed the most important factors. Certainly more synoptic observations on a larger regional scale during winter are needed to understand the strategies and their control in the North Sea.

Acknowledgments We thank the crew of RV 'Aade' of the Biologische Anstalt Helgoland (BAH) for reliable plankton sampling and logistic support. Thanks are due to the biological oceanography group of the $\mathrm{BAH}$ for determining hydrography and phytoplankton, to U. Holtz for measuring copepod prosome lengths, and to M. Boersma for critical comments on the manuscript. R. Schwamborn and T. Brey helped with the statistics. This 
study was funded by the German federal ministry of education and research (BMBF) as a part of the GLOBEC-Germany program $(03 \mathrm{~F} 0320 \mathrm{C})$.

\section{References}

Banner FT, Collins MB, Massie KS (1980) The north-west European Shelf seas: the sea bed and the sea in motion. II. Physical and chemical oceanography, and physical resources. Elsevier, New York

Beare DJ, Batten S, Edwards M, Reid DG (2002) Prevalence of boreal Atlantic, temperate Atlantic and neritic zooplankton in the North Sea between 1958 and 1998 in relation to temperature, salinity, stratification intensity and Atlantic inflow. J Sea Res 48:29-49

Box GEP, Jenkins GM (1976) Time series analysis: forecasting and control. Holden-Day. San Francisco

Castellani C, Lucas IAN (2003) Seasonal variation in egg morphology and hatching success in the calanoid copepods $T e$ mora longicornis, Acartia clausi and Centropages hamatus. $\mathrm{J}$ Plankt Res 25:527-538

Castro-Longoria E, Williams JA (1999) The production of subitaneous and diapause eggs: a reproductive strategy for Acartia bifilosa (Copepoda: Calanoida) in Southampton Water, UK. J Plankt Res 21:65-84

Daan R, Gonzalez SR, Klein Breteler WCM (1988) Cannibalism in omnivorous calanoid copepods. Mar Ecol Prog Ser 47:45-54

Dahms HU (1995) Dormancy in the Copepoda-an overview. Hydrobiol 306:199-211

Danks HV (1987) Insect dormancy: an ecological perspective. Tyrell Press, Gloucester

Edwards M, Beaugrand G, Reid PC, Rowden AA, Jones MB (2002) Ocean climate anomalies and the ecology of the North Sea. Mar Ecol Prog Ser 239:1-10

Edwards M, Richardson AJ (2004) Impact of climate change on marine pelagic phenology and trophic mismatch. Nature 430:881-884

Edwards M, Licandro P, John AWG, Johns DG (2005) Ecological status report 2003/2004: results from the CPR survey 2003/2004. SAHFOS Tech Rep 2:6 pp

Engel M, Hirche HJ (2004) Seasonal variability and inter-specific differences in hatching of calanoid copepod resting eggs from sediments of the German Bight (North Sea). J Plankt Res 26:1083-1093

Fransz HG (1975) The spring development of calanoid copepod populations in Dutch coastal waters as related to primary production. In tenth European symposium on marine biology, Ostend, Belgium, Sept 17-23, 2:247-269

Fransz HG, Colebrook JM, Gamble JC, Krause M (1991) The zooplankton of the North Sea. Neth J Sea Res 28:1-52

Gaudy R (1972) Contribution à la connaissance du cycle biologique des copépodes du Golfe de Marseille. 2. Étude du cycle biologique des quelques espèces charactéristiques. Téthys 4:175-242

Greve W, Reiners F, Nast J, Hoffmann S (2004) Helgoland Roads meso- and macrozooplankton time-series 1974-2004: lessons from 30 years of single spot, high frequency sampling at the only off-shore island of the North Sea. Helgol Mar Res 58:274-288

Halsband C, Hirche HJ (2001) Reproductive cycles of dominant calanoid copepods in the North Sea. Mar Ecol Prog Ser 209:219-229

Halsband-Lenk C, Carlotti F, Greve W (2004) Life-history strategies of calanoid congeners under two different climate regimes: a comparison. ICES J Mar Sci 61:709-720
Hay S (1995) Egg production and secondary production of common North Sea copepods: field estimates with regional and seasonal comparisons. ICES J mar Sci 52:315-327

Hickel W (1975) The mesozooplankton in the Wadden Sea of Sylt (North Sea). Helgol Mar Res 27:254-262

Hickel W, Berg J, Treutner K (1992) Variability in phytoplankton biomass in the German Bight near Helgoland, 1980-1990. ICES Mar Sci Symp 195:249-259

Hillebrand H, Dürselen C-D, Kirschtel D, Pollingher U, Zohary $\mathrm{T}$ (1999) Biovolume calculation for pelagic and benthic microalgae. J Phycol 35:403-424

Hirche HJ (1998) Dormancy in three Calanus species (C. finmarchicus, C. glacialis and C. hyperboreus) from the North Atlantic. In: Evolutionary and ecological aspects of crustacean diapause. Adv Limnol 52:359-369

Ianora A, Buttino I (1990) Seasonal cycles in population abundances and egg production rates in the planktonic copepods Centropages typicus and Acartia clausi. J Plankt Res 12:473481

Ianora A, Scotto di Carlo B (1988) Observations on egg production rates and seasonal changes in the internal morphology of Mediterranean populations of Acartia clausi and Centropages typicus. Hydrobiol 167/168:247-253

Kiørboe T, Nielsen TG (1994) Regulation of zooplankton biomass and reproduction in a temperate, coastal ecosystem. 1. Copepods. Limnol Oceanogr 39:493-507

Klein Breteler WCM, Schogt N (1994) Development of Acartia clausi (Copepoda, Calanoida) cultured at different conditions of temperature and food. Hydrobiol 292/293:469 479

Krause M, Dippner JW, Beil J (1995) A review of hydrographic controls on the distribution of zooplankton biomass and species in the North Sea with particular reference to a survey conducted in January-March 1987. Prog Oceanogr 35:81152

Kruskal WH, Wallis WA (1952) Use of ranks in one-criterion variance analysis. J Amer Statist Ass 47:614-617

Landry MR (1978) Population dynamics and production of a planktonic marine copepod, Acartia clausii, in a small temperate lagoon on San Juan Island, Washington. Int Rev Gesamt Hydrobiol 63:77-119

Le Ruyet-Person J, Razouls C, Razouls S (1975). Biologie comparée entre espèces vicariantes et communes de copépodes dans un écosystème néritique en Méditerranée et en Manche. Vie Milieu 25B:283-312

Lindley JA (1986) Dormant eggs of calanoid copepods in sea-bed sediments of the English Channel and the southern North Sea. J Plankt Res 8:399-400

Lindley JA (1990) Distribution of overwintering calanoid copepod eggs in sea-bed sediments. Mar Biol 104:209-217

Lindley JA, Reid PC (2002) Variations in the abundance of Centropages typicus and Calanus helgolandicus in the North Sea: deviations from close relationships with temperature. Mar Biol 141:153-165

Marcus NH (1996) Ecological and evolutionary significance of resting eggs in marine copepods: Past, present, and future studies. Hydrobiol 320:141-152

Marshall SM, Orr AP (1958) On the biology of Calanus finmarchicus. X. Seasonal changes in oxygen consumption. J Mar Biol Ass UK 37:459-472

Miralto A, Ianora A, Poulet SA (1995) Food type induces different reproductive responses in the copepod Centropages typicus. J Plankt Res 17:1521-1534

Naess T (1996) Marine calanoid resting eggs in Norway: Abundance and distribution of two copepod species in the sediment of an enclosed marine basin. Mar Biol 110:261-266 
Norrbin MF (2001) Ultra-structural changes in the reproductive system of overwintering females of Acartia longiremis. Mar Biol 139:697-704

Ohman MD, Hirche HJ (2001) Density-dependent mortality in an oceanic copepod population. Nature 412:638-641

Otto L, Zimmermann JTF, Furnes GK, Mork M, Saetre R, Becker G (1990) Review of the physical oceanography of the North Sea. Neth J Sea Res 26:161-238

Radach G, Berg J, Hagmeier E (1990) Long-term changes of the annual cycles of meteorological, hydrographic, nutrient and phytoplankton time series at Helgoland and LV Elbe 1 in the German Bight. Cont Shelf Res 10:305-328

Rae KM, Rees CB (1947) Continuous Plankton Records: the copepoda of the North Sea, 1938-39. Hull Bull Mar Ecol 2:95132

Reid PC, Lancelot C, Gieskes WWC, Hagmeier E, Weichert G (1990) Phytoplankton of the North Sea and its dynamics: A review. Neth J Sea Res 26:295-331
Reid PC, Edwards M, Beaugrand G, Skogen M, Stevens D (2003) Periodic changes in the zooplankton of the North Sea during the twentieth century linked to oceanic inflow. Fish Oceanogr 12:260-269

Riccardi N, Mariotto L (2000) Seasonal variations in copepod body length: a comparison between different species in the Lagoon of Venice. Aquat Ecol 34:243-252

Sell AF, van Keuren D, Madin LP (2001) Predation by omnivorous copepods on early developmental stages of Calanus finmarchicus and Pseudocalanus spp.. Limnol Oceanogr 46:953-959

Wiborg KF (1955) Zooplankton in relation to hydrography in the Norwegian Sea. Fisk Direkt Skri, Ser Havundersök 11:1-66

Wilson DF, Parrish KK (1971) Remating in a planktonic marine calanoid copepod. Mar Biol 9:202-204

Wiltshire KH, Manly BFJ (2004) The warming trend at Helgoland Roads, North Sea: phytoplankton response. Helgol Mar Res 58:269-273 